\title{
Sanitary situation of Aleppo pine and holm oak on the Sidi R'Ghies forest, Algeria
}

\author{
MALIKA RACHED-KANOUNI ${ }^{1}$, ZAHIA KADI ${ }^{1}$, HICHEM KHAMMAR ${ }^{1, \vartheta}$, RATIBA BOUSBA ${ }^{2}$, \\ ROMAISSA AMRANE ${ }^{1}$, BESMA CHELLAL ${ }^{1}$, LABED ABABSA $^{1}$ \\ ${ }^{1}$ Laboratory of Functional Ecology and Environment, Department of Life and Nature Sciences, Faculty of Exact Sciences and Life and Nature Sciences, \\ University of Larbi Ben M'hidi, Oum El Bouaghi. 1 November 1954 Street, Oum El Bouaghi 04000, Algeria \\ "email: khammar.eco.env@gmail.com \\ ${ }^{2}$ Laboratory of Genetic, Biochemistry and Plant Biotechnology, Department of Biology and Ecology, Faculty of Nature and Life Sciences, University des \\ Frères Mentouri Constantine 1. Route Ain el Bey, 25000 Constantine, Algeria
}

Manuscript received: 1 July 2020. Revision accepted: 5 August 2020.

\begin{abstract}
Rached-Kanouni M, Kadi Z, Khammar H, Bousba R, Amrane R, Chellal B, Ababsa L. 2020. Sanitary situation of Aleppo pine and holm oak on the Sidi R'Ghies forest, Algeria. Biodiversitas 21: 3954-3960. The present work aims to assess the vitality status of the Sidi R'Ghies forest and its evolution over time. Eight plots (4 plots for Aleppo pine and 4 for holm oak) were selected at random. The data collected on sample trees are analyzed using two methods: ARCHI, which is based on a reading of the tree architecture, and the assessment of biodiversity using the potential biodiversity index (PBI). The diagnostic results show that the majority of the se plots are subject to climatic, pedological, and anthropogenic stresses and their health status is quite low. Despite the pressures and threats to the massif, it remains viable. But this potential is insufficient. To this end, silvicultural interventions are necessary to ensu re the viability of this ecosystem by promoting the regeneration of species differences and to include a permanent ecological monitoring system.
\end{abstract}

Keywords: ARCHI, health status, PBI, Sidi R'Ghies

\section{INTRODUCTION}

As scientific knowledge improves, the multiple ecological qualities of forests are revealed. Well beyond the notions of diversity or species richness alone, key functional qualities of a forest ecosystem are being highlighted: maturity, age, dynamics and resilience, indigenously, continuity in space, etc. Certain indicators relating to these qualities are now commonly accepted, studied, and monitored (e.g. those describing deadwood). However, not all the qualities of an ecosystem are equally shared. Often grouped, for the sake of simplification, under the term naturalness, they remain a field of debate between scientists and managers (Vallauri et al. 2010; Dudley 2011; Rached-Kanouni et al. 2020), which is all the richer as a forest is a complex ecosystem.

Over the last twenty years, evaluation approaches have developed and have taken a major role. The world of forestry and nature is no exception. Pastorella and Paletto (2013) recall, "evaluation is not management", evaluation approaches have become a useful tool to guide the manager's choices. They cover all scales, policies, and themes, including sustainable management and biodiversity.

Emerging at the same time, the issue of biodiversity has given rise to rich theoretical and applied exchanges on the subject (Deconchat and Balent 2004; Barbati et al. 2012; Barbeito et al. 2014). Managers have drawn inspiration from this to produce practical tools, such as the Potential Biodiversity Index (PBI), to guide the silviculturist in current management (Gonin and Larrieu 2012; Gonin et al. 2012; Larrieu et al. 2012; Emberger et al. 2013). The Architectural Tree Analysis Method (ARCHI) consists of visual analysis of the crown of a tree, to assess its health status and in particular, it is level of dieback. This diagnosis does not only take into account the number of dead branches: the ARCHI method is also interested in the number of greedy branches produced by the tree to compensate for its descent from the crown and which indicates its resilience capacity (Drénou et al. 2011; Nageleisen 2012).

The forest of Sidi R'Gheis is characterized by a special vegetation cover different from the other areas of the Oum El Bouaghi region. This is due to the importance of its surface estimated at 3106 ha and to the altitude which varies between $1030 \mathrm{~m}$ and $1635 \mathrm{~m}$ like the mountainous reliefs which characterize the Aures chain. It appears through these characteristics that the quantity of rainfall in this mountainous area is quite important despite the situation of the region of Oum El Bouaghi in the semi-arid bioclimatic stage with acute climatic differences. Having an influence on the nature and composition of the soils and consequently on the plant cover and its development, this has resulted in the diversity of plant species (RachedKanouni et al. 2020). The plant groups that exist today are not the product of the succession of different phases that are subject to change over time, but their essential reason is due to human intervention. To evaluate the current status of vitality and its evolution over the years, the Sidi R'Ghies massif must be equipped with a health monitoring systems. 
Pure stands or mixtures of the majority species which have an ecological and socio-economic interest, namely Aleppo pine (Pinus halepensis) and holm oak (Quercus ilex) are observed every year in summer.

The main objectives of monitoring the health status are, on the one hand, to assess the current status of health of the Sidi R'Ghies forest and, on the other hand, to initiate the formation of a database to analyze its evolution and identify possible trends. For the 2019 campaign, our observations required a field diagnosis mainly based on the ARCHI and PBI methods. It will then be possible to take them into account in management actions to conserve or improve the biodiversity associated with them.

\section{MATERIALS AND METHODS}

\section{Presentation of the study area}

Oum El Bouaghi $\left(34^{\circ} 70^{\prime} \mathrm{N}\right.$ to $36^{\circ} 20^{\prime} \mathrm{N}$ and $4^{\circ} 80^{\prime} \mathrm{E}$ to $\left.7^{\circ} 60^{\prime}\right)$ is located in the North of Algeria in the Constantine Highlands region (Figure 1), and covers an area of 7638.13 $\mathrm{km}^{2}$. The mount of Sidi R'Ghies is located in the North of the city of Oum El Bouaghi between the lines of latitude $35^{\circ} 52^{\prime} 5^{\prime \prime}$ in the South and $35^{\circ} 57^{\prime}$ in the North and between the lines of longitude $07^{\circ} 06^{\prime}$ in the West and $07^{\circ}$ $10^{\prime}$ in the East of the Greenwich meridian.

\section{Choice of study station}

It is not possible to cover the whole area of the Sidi R'Ghies massif, it is, therefore, necessary to sample the existing environments and choose representative sites. We chose the study plots with the floristic composition and the altitude. The chosen sampling is random. The chosen plots ( 4 for Aleppo pine and 4 for holm oak) have rectangular shapes; each plot has an area equivalent to $1000 \mathrm{~m}^{2}$. The geographical coordinates of each plot are taken with GPS.

\section{Data collection}

Data collection takes place at two levels: Observations that provide qualitative data can be complete (considering all individuals) or partial (focusing on a few individuals); Counting and measuring quantitative data requires welldefined physical devices. Within each plot, the traditional diameter at $1.30 \mathrm{~m}$ from the ground (BHD: breast height) was for all species including $B H D \geq 2 \mathrm{~cm}$. The total height was measured using Bloom Lies on individuals of characteristic and valuable forest species by diameter class and plot.

\section{Tree Architecture Method (ARCHI): Appearance of tree crowns}

To characterize the health status of our stands, the institute for forest development has developed a diagnostic tool called the ARCHI method, which is based on a reading of tree architecture (Drénou et al. 2013; Eichhorn et al. 2016). The principle is to carry out two series of observations: the first concerns the symptoms of crown degradation (leaf deficit, abnormal coloring, mortality, etc.), and the second concerns crown restoration processes (development of greedy, wound recovery, growth recovery, etc.). The study of the balance of power between these antagonistic degradation-restoration processes enables a diagnosis to be made on the tree.

\section{Stand Potential Biodiversity Index (PBI)}

The Stand Potential Biodiversity Index (PBI) consists of assessing a set of ten factors among those usually recognized as the most favorable to the internal diversity of forest stands (Siitonen 2001; Müller and Bütler 2010; Gosselin 2012; Gosselin et al. 2012; Gosselin 2016). We considered stand specific composition and structure, the supply of tree-related "micro-habitats", the presence of forest-associated habitats, the maturity of current stands, and the continuity of the wooded condition. Open wet and rocky environments are taken into account for the originality of their specific composition and for the functional role they play for forest stands (Maitre d'Hôtel and Pelegrin 2012).

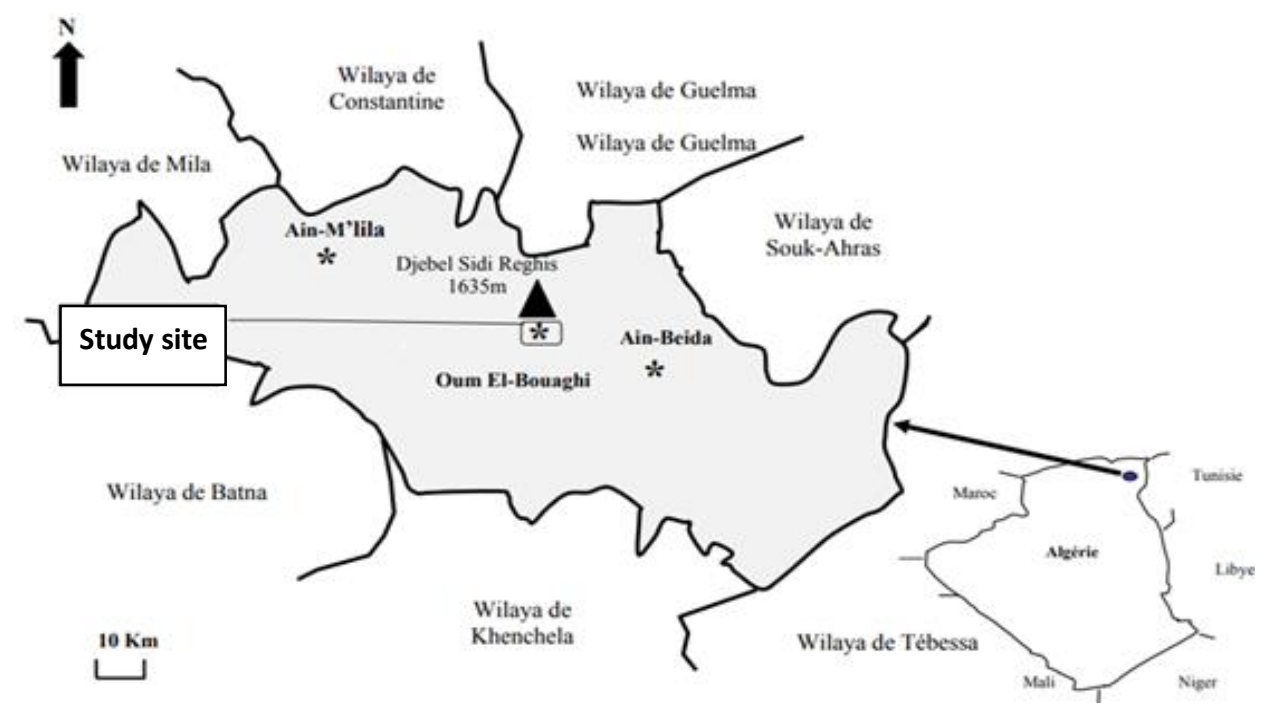

Figure 1. Map of the geographical location of Sidi R'Ghies, Algeria 
Each factor is assigned a score, regarding a scale of threshold values. The sum of the scores then makes it possible to assess overall diversity with a theoretical maximum level of biodiversity (Vuidot et al. 2011).

Seven factors are directly dependent on stand and management: Aboriginal species (A), vertical structure of vegetation (B), standing deadwood (C), deadwood on the ground (D), very large live wood (E), live trees bearing microhabitats (F) (Winter and Möller 2008), open environments $(\mathrm{g})$ and three others are more context-related: temporal continuity of the wooded state $(\mathrm{H})$, aquatic environments (I), rocky environments (J) (Larrieu et al. 2011; Cockle et al. 2012). A score of 0, 2 or 5 is given to each of the factors according to a scale of threshold values. The PBI was designed to be used at the forest stand scale, which corresponds to the most common operational level. The minimum area that can be scored is set at 0.25 ha, with the maximum limit being reached when the stand changes significantly. The results are synthesized in the form of a "radar" graph in a spreadsheet that facilitates both the comparison of stands, their monitoring over time, and the diagnosis of factors that should be improved.

\section{RESULTS AND DISCUSSION}

\section{Results}

The results obtained on 8 plots (4 holm oak and 4 Aleppo pine plots) are shown in Figure 2. Nominal values of Aleppo pine were observed in the ARCHI S and ARCHI $\mathrm{R}$ types, while minimum values were recorded in the ARCHI Health, ARCHI D, and ARCHI I types. In the ARCHI $S$ type, the highest value was recorded in plots 2 and 4 (14 and 21 in order). The maximum value of type ARCHI $\mathrm{R}$ is obtained in the $1^{\text {st }}$ plot and then the minimum values are around 15 trees in the other plots. The smallest values are noted for the ARCHI Health, ARCHI D, and ARCHI I types; they vary from 0 to 2 . Concerning the holm oak, the large number of trees is of the ARCHI S type $(58 \%)$; the ARCHI R type comes in second place with a percentage of $30 \%$. Healthy ARCHI and ARCHI I trees have only 6 and $4 \%$ respectively. The ARCHI D type is absent.

In addition to the ARCHI method, the IBP index is proposed for assessing the health status of the Sidi R'Gheis forest massif, which is a quick and simple tool (Larrieu and Cabanettes 2012). The PBI has been tested according to several procedures. We tested it on an area of 0.8 ha $(8$ plots). A score of 2 is given to the first holm oak plot characterized by three genera, while a score of 5 is given to plots 2, 3, and 4 where the number of genera is greater than 3 . Regarding the vertical structure of the vegetation, the number 5 for plot 1 means that there are 4 strata within this plot (herbaceous stratum, height " $\mathrm{H}$ " < 5 m, H between 5-15 $\mathrm{m}, \mathrm{H}>15 \mathrm{~m}$ ); on the other hand, a score of 2 is given to the other plots characterizing fewer vegetation strata. For all the plots, standing dead wood, ground biting and very large woods are absent (0). Context-related factors are represented by the microhabitats (lichens) existing on the majority of sample trees, for which the score is 5 (Figure 2,
Table 1). A score of 2 in plots 1,3 , and 4 indicates the presence of open habitats, while the absence of open habitats is found in plot 2 and corresponds to 0 . The maximum age class of the study plots is 60 years, which means that the temporal continuity of the wooded condition is absent (score $=0$ ). Rocky environments are common and aquatic environments are found in plots 2, 3, and 4 (Table 2).

Native species, standing and ground dead wood and very large woods are absent on all Aleppo pine plots (score $=0$ ). Vegetation in plots 1 and 3 consists of three strata and has a score of 2; on the other hand, it is characterized by a low number of strata in plots 2 and 4 (the score is 0 ). Two types of microhabitats (Lichens and Pine processionary) are observed in the set of plots, from which the score is 5 (Figure 4, Table 3). All plots contain open habitats (category 5). The absence of aquatic environments and the age of the (young) trees contribute 0 and the existence of a single rocky environment gives them a score of 2 (Table 4).

\section{Discussion}

Knowledge of the architecture of trees of a large number of species has enabled the transposition of these notions to forestry technicians and has led to the implementation of observation protocols to establish a diagnosis of the architecture giving indications on the level of stress suffered by the tree, to establish its reactivity and therefore to propose a prediction of the evolution of its architecture (Drénou 2014; Drénou and Caraglio 2019). The ARCHI diagnostic method was developed in order to provide managers with the simplest possible decisionmaking tool enabling them to carry out a health analysis of the stands and to extract information on the interventions to be recommended (Drénou et al. 2011; 2012).

The study presented aims to establish the vitality status of the Sidi R'Ghies forest massif using a diagnosis on 8 plots. A first assessment of the crown health status is carried out using the ARCHI method, which is based on a morphological analysis of the entire aerial part based on observation. The keys integrate three series of observations: the sequential structure set up during growth, which provides information on the tree's development stage, symptoms of degradation, tree crown architecture (mortality, branching impoverishment), and finally the crown restoration processes resulting mainly from the development of epicormic twigs (Eichhorn et al. 2010; Drénou et al. 2013).

Trees of the ARCHI S and ARCHI R types form the majority of oak trees, and some trees of the healthy type and ARCHI I type; this explains why $60 \%$ of trees have low vigorous greedy, or low vigorous greedy and $40 \%$ of trees have a preponderance over the A2 and presence of numerous vigorous greedy. The presence of mortality in the crown is notable (dense or sparse foliage), but this mortality is limited to A3 for plots 1, 2, and 4. The opposite is found in the case of the $3^{\text {rd }}$ plot.

Coupled analysis of the health diagnosis (carried out in 2010) and tree growth dynamics since 1950 clearly shows that the current health status reveals past losses of vitality largely related to past extreme droughts. Thus, 1976, with a 
summer water deficit nearly double the normal (+90\%) appears to be a pivotal year with an amplification of the discrimination of growth curves. Less than 20 years after this first crisis, the equally exceptional droughts of 1989 and $1990(+50$ to $+60 \%$ of the normal deficit) put a brake on growth. Subsequent droughts (1996, 2003, 2004) "hammered the nail in" by preventing moribund trees from recovering sufficient growth levels to rebuild a functional canopy. As was observed for fir dieback in the Vosges and Jura (Lebourgeois et al. 2013) or oak forests in the plains (Lévy et al. 1994) in the late 1980s, extreme years and their repetition are indeed the factors triggering growth losses, and crown condition ratings reveal many past stresses that can go back as far as 20 or 30 years. For resilient and healthy trees, growth is also strongly stopped under extreme stresses but the level of growth remains higher.

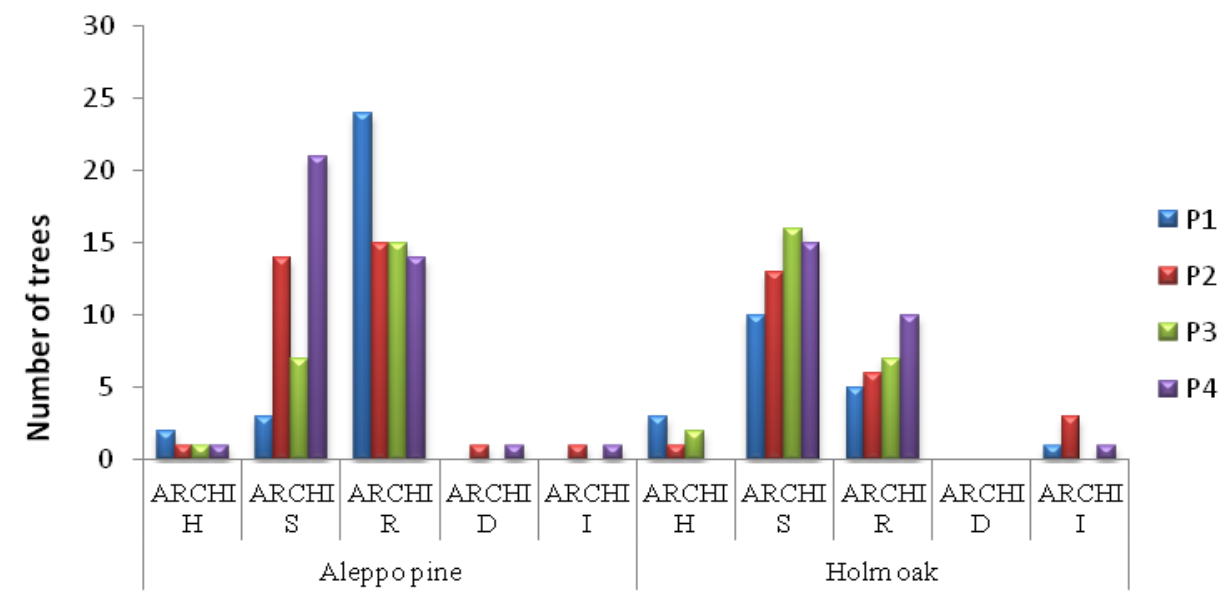

Figure 2. The different types of ARCHI of Aleppo pine and holm oak

Potential biodiversity related to stand and forest management Plot 1

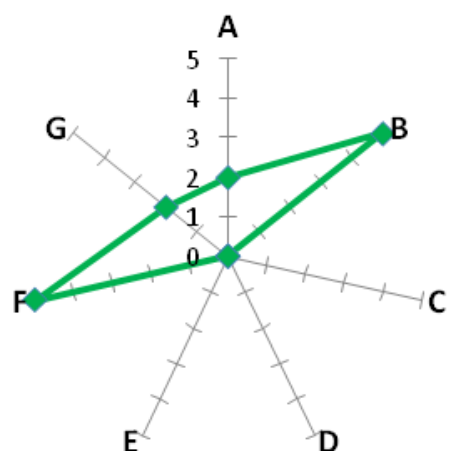

Plot 2

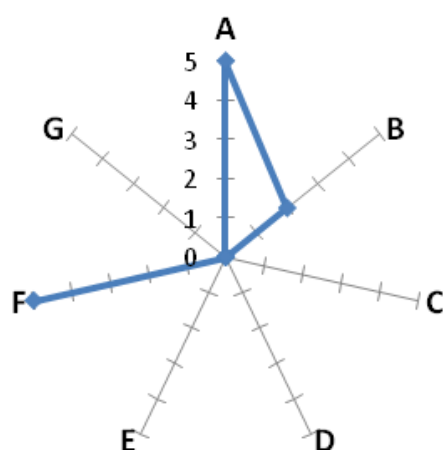

Plots 3-4

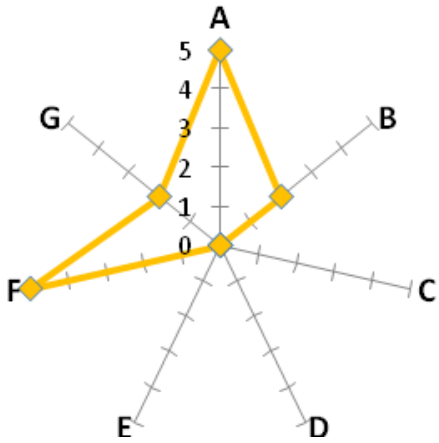

Context-related potential biodiversity Plot 1

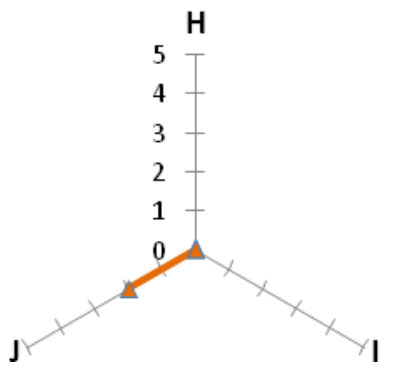

Plots 2-3-4

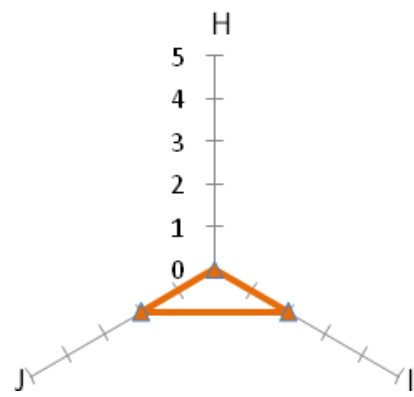

Figure 3. Graphical representation of PBI compared to 4 holm oak plots 
Potential biodiversity related to stand and forest management Plots 1-3

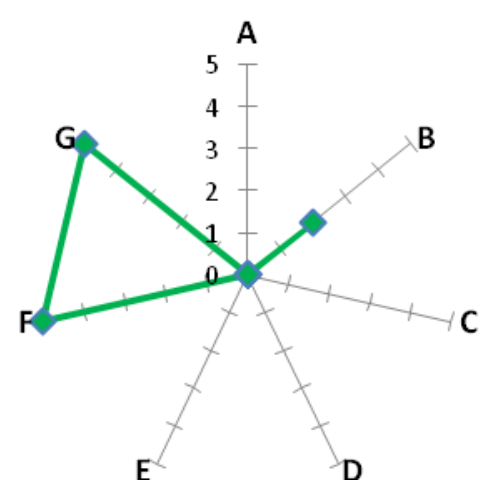

Plots 2-4

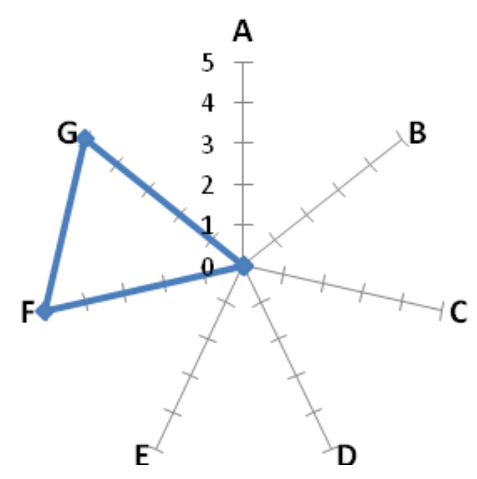

Context-related potential biodiversity Plots 1-2-3-4

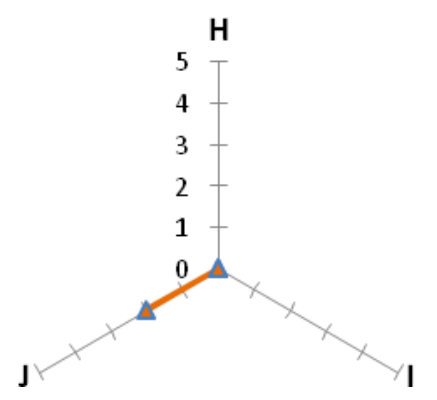

Figure 4. Graphical representation of PBI compared to 4 Aleppo pine plots

Table 1. Potential biodiversity related to the holm oak settlement and management $\left(1^{\text {st }}\right.$ value $)$

\begin{tabular}{lccc}
\hline Plots & $\begin{array}{c}\text { Absolute } \\
\text { value }\end{array}$ & $\begin{array}{c}\text { Relative value } \\
\text { \% Theoretical } \\
\text { maximum value) }\end{array}$ & $\begin{array}{c}\text { Potential Biodiversity } \\
\text { related to settlement } \\
\text { and management }\end{array}$ \\
\hline P1 & 14 & $40 \%$ & Medium \\
P2 & 12 & $35 \%$ & Fairly low \\
P3 & 14 & $40 \%$ & Medium \\
P4 & 14 & $40 \%$ & Medium \\
\hline
\end{tabular}

Table 2. Potential biodiversity linked to the holm oak context ( $2^{\text {nd }}$ value)

\begin{tabular}{lccc}
\hline Plots & $\begin{array}{c}\text { Absolute } \\
\text { value }\end{array}$ & $\begin{array}{c}\text { Relative value } \\
\text { (\% Theoretical } \\
\text { maximum value) }\end{array}$ & $\begin{array}{c}\text { Potential biodiversity } \\
\text { related to settlement } \\
\text { and management }\end{array}$ \\
\hline P1 & 2 & $13 \%$ & Fairly important \\
P2 & 4 & $26 \%$ & Fairly important \\
P3 & 4 & $26 \%$ & Fairly important \\
P4 & 4 & $26 \%$ & Fairly important \\
\hline
\end{tabular}

ARCHI R type trees with its characteristics are: In the absence of additional stress, this type will revert to the healthy type. In terms of the width of the rings formed, after a period of decay, the radial progression recovers. A resilient oak is potentially a tree of the future, provided that the $\log$ is of good quality and the plant is capable of producing timber. As with ARCHI S type trees (A stress condition), it is not possible to make a statement on the tree's future (Lebourgeois et al. 2015). Either the stress is too recent, or the five architectural descriptors used are insufficient to make prognosis. Thus, starting from a normal state, under the influence of various factors, there may be deviations from normal followed by returns to normal. This cyclical behavior is not uncommon. In our study, the results obtained indicate that the majority of trees are of the ARCHI R and ARCHI S type in the Aleppo pine
Table 3. Potential biodiversity related to the Aleppo pine settlement and management ( $1^{\text {st }}$ value $)$

\begin{tabular}{cccc}
\hline Plots & $\begin{array}{c}\text { Absolute } \\
\text { value }\end{array}$ & $\begin{array}{c}\text { Relative value } \\
\text { (\% Theoretical } \\
\text { maximum value) }\end{array}$ & $\begin{array}{c}\text { Potential biodiversity } \\
\text { related to settlement } \\
\text { and management }\end{array}$ \\
\hline P1 & 17 & $48 \%$ & Medium \\
P2 & 15 & $43 \%$ & Medium \\
P3 & 17 & $48 \%$ & Medium \\
P4 & 15 & $43 \%$ & Medium \\
\hline
\end{tabular}

Table 4. Potential biodiversity linked to the Aleppo pine context $\left(2^{\text {nd }}\right.$ value $)$

\begin{tabular}{lccl}
\hline Plots & $\begin{array}{c}\text { Absolute } \\
\text { value }\end{array}$ & $\begin{array}{c}\text { Relative value } \\
\text { (\% Theoretical } \\
\text { maximum value) }\end{array}$ & $\begin{array}{c}\text { Potential biodiversity } \\
\text { related to settlement } \\
\text { and management }\end{array}$ \\
\hline P1 & 2 & $13 \%$ & Fairly important \\
P2 & 2 & $13 \%$ & Fairly important \\
P3 & 2 & $13 \%$ & Fairly important \\
P4 & 2 & $13 \%$ & Fairly important \\
\hline
\end{tabular}

and holm oak plots, which can be explained by the influence of various ecological factors in the study area characterized by rocky soil and a semi-arid climate.

Climate analysis confirms this greater sensitivity of currently moribund trees to summer droughts, which have always played a major role in their growth by influencing both the setting of initial and final wood. For healthy trees, the importance of water deficit is less important but it appears that its role has increased significantly in recent years with determinism of the establishment of the ring, which also becomes "water balance-dependent". This change in tree response over time has already been observed in many contexts across Europe (Lebourgeois and Mérian 2011) and is often interpreted as a homogenization of the response of ecosystems to increasing environmental constraints. 
Concerning resilience, trees qualified as resilient from an architectural point of view also appeared to be resilient from a growth point of view with a capacity to recover the pre-crisis level of growth or even to present a higher level. The visual diagnosis implemented since 2011 is therefore in good adequacy with the dynamics of radial growth. Moribund trees are trees that have been growing very little (less than $1.5 \mathrm{~mm}$ on the radius) for many years and whose resilience (in terms of growth) is less than other architectural types. Resilient trees are capable of recovering more strongly after a crisis and thus of establishing a functional crown (Lebourgeois et al. 2015).

The second assessment of biodiversity using the Potential Biodiversity Index (PBI): is a simple and quick tool that allows forest managers (Du Bus De Warnaffe and Devillez 2002): (i) estimate the potential taxonomic biodiversity of the stand; (ii) diagnose elements that can be improved through management.

The results show that potential forest biodiversity is quite low in the Sidi R'Ghies massif. The average or rather low values of the criteria in the studied plots often depend on climate, soil, and anthropic actions.

The Potential Biodiversity Index is composed of two scores which are the sub-totals of the values obtained, on the one hand, for the factors dependent on forest management and the other hand for the factors that are independent of it. The PBI is expressed by keeping the two components of the overall score separate and scoring each as a percentage of the theoretical maximum score. PBI is expressed by keeping the two components of the overall score separate and scoring each as a percentage of the maximum theoretical score.

For example, a stand of holm oak (plots 1, 3, and 4) with the first score of 14 and the second score of 4 (PBI $40 \%$ and 26\%). According to the values obtained, the potential biodiversity is judged according to the average rating scale for the first score and quite significant for the second score. In particular, the PBI does not, for practical reasons, integrate the genetic and ecosystem dimensions of biodiversity and does not provide information on diversity at the landscape scale (diversity), a level corresponding to that of the management of a property or a forest massif (Larrieu et al. 2012). Furthermore, it does not take into account the soil and the possible impacts of forest interventions, such as compaction or rutting. In most cases, these elements require pedological investigations, the implementation of which would hamper the speed of scoring, and their relationship with specific diversity is not always obvious (Mikusinnski and Ranius 2002).

$\mathrm{PBI}$ is not a tool for assessing the conservation status of a natural habitat because the rating does not take into account the stationary compartment and the communities present, nor certain functional criteria that may be crucial for habitat conservation (e.g. water regime for alluvial forests). Nevertheless, it could be usefully integrated into a grid for assessing the conservation status of habitats. Similarly, since PBI does not incorporate the observation of direct traces of anthropization or the verification of the integrity of functional groups, it is not a tool for assessing the naturalness of stands either, but a stand with a high degree of naturalness will necessarily have a strong PBI value. PBI is part of a sustainable forest management approach, which requires the assessment of other elements, including forest health and vitality.

In conclusion, the massif of Sidi R'Ghies is considered as a very rich forest area in terms of biological diversity. This forest is mainly composed of holm oak and Aleppo pine which are currently in a degraded state due to various natural and anthropic factors. The objective of this work is to know the health status of these two species using the ARCHI and PBI method. The diagnostic results show that holm oak and Aleppo pine are subject to climatic, pedological, and anthropogenic stresses and their health status is quite low. It is important to take into account the results obtained to establish a management plan to protect this forest massif against various degradation factors.

\section{REFERENCES}

Barbati A, Salvati R, Ferrari B, Di Santo D, Quatrini A, Portoghesi L, Travaglini D, Iovino F, Nocentini S. 2012. Assessing and promoting old growths of forest stands lessons from research in Italy. Plant Biosyst 146 (1): 167-174.

Barbeito I, Collet C, Ningre F. 2014. Crown responses to neighbour density and species identity in a young mixed deciduous stand. Trees 28: 1751-1765.

Cockle KL, Martin K, Robledo G. 2012. Linking fungi, trees, and holeusing birds in a Neotropical tree-cavity network: Pathways of cavity production and implications for conservation. For Ecol Manag 264: 210-219.

Deconchat M, Balent G. 2004. Critères et indicateurs de gestion durable: la biodiversité. Rev For Fr 46 (5): 419-430.

Drénou C, Bouvier M, Lemaire J. 2011. La méthode de diagnostic ARCHI, application aux chênes pédonculés dépérissants. Forentreprise 200: 4-15.

Drénou C, Bouvier M, Lemaire J. 2012. Rôles des gourmands dans la résilience des chênes pédonculés dépérissants. For Wallonne 116 (1): 42-55.

Drénou C, Caraglio Y. 2019. «Parlez-vous Archi?» Les principales définitions de la méthode Archi. For-entreprise 246: 28-35.

Drénou C, Giraud F, Gravier H, Sabatier S, Caraglio Y. 2013. Le diagnostic architectural : un outil d'évaluation des sapinières dépérissantes. For Méditerr Tome 34 (2): 87-98.

Drénou C. 2014. Du gourmand au suppléan ou de la réhabilitation du gourmand en arboriculture et en sylviculture. La Forêt Privée 340: 5157.

Du Bus De Warnaffe G., Devillez F. 2002. Quantifier la valeur écologique des milieux pour intégrer la conservation de la nature dans l'aménagement des forêts: une démarche multicritères. Ann For Sci 59: 369-387.

Dudley N. 2011. Authenticity in Nature: Making Choices about the Naturalness of Ecosystems. Earthscan, London.

Eichhorn J, Roskams P, Ferretti M, Mues V, Szepesi A, Durrant D. 2010. Visual Assessment of Crown Condition and Damaging Agents. Manual Part IV. In: Manual on methods and criteria for harmonized sampling, assessment, monitoring and analysis of the effects of air pollution on forests. UNECE ICP Forests Programme Co-ordinating Centre, Hamburg. http: //www.icp-forests.org/Manual.htm

Eichhorn J, Roskams P, Potočić N, Timmermann V, Ferretti M, Mues V, Szepesi A, Durrant D, Seletković I, Schrock H-W, Nevalainen S, Bussotti F, Garcia P, Wulff S. 2016. Part IV: Visual Assessment of Crown Condition and Damaging Agents. In: UNECE ICP Forests Programme Coordinating Centre (ed): Manual on methods and criteria for harmonized sampling, assessment, monitoring and analysis of the effects of air pollution on forests. Thunen Institute of Forest Ecosystems, Eberswalde, Germany. http: //www.icpforests.org/manual.htm

Emberger C, Larrieu L, Gonin P. 2013. Dix facteurs clés pour la diversité des espèces en forêt. Comprendre l'Indice de Biodiversité Potentielle 
(IBP). Document technique. Institut pour le développement forestier, Paris.

Gonin P, Larrieu L, Martel S. 2012. L'Indice de Biodiversité Potentielle (IBP) en région méditerranéenne. For Méditerr 33 (2): 133-141. [France]

Gonin P, Larrieu L. 2012. Méthodes de relevé de l'Indice de Biodiversité Potentielle (IBP). IDF-CNPF, INRA Dynafor v3.3, mars 2013, 13 p. [France]

Gosselin F, Gosselin M, Paillet Y. 2012. Suivre l'état de la biodiversité forestière : pourquoi ? Comment? Rev For Fr 64 (5): 683-700

Gosselin F. 2012. Improving approaches to the analysis of functional and taxonomic biotic homogenization: beyond mean specialization. J Eco 100: 1289-1295.

Gosselin F. 2016. Putting floristic thermophilization in forests into a conservation biology perspective: beyond mean trait approaches. Ann For Sci 73: 215-218.

Larrieu L, Cabanettes A, Delarue A. 2011. Impact of sylviculture on dead wood and on the distribution and frequency of tree microhabitats in mountain beech-fir forests of the Pyrenees. Eur J For Res 131 (3): 773-786.

Larrieu L, Cabanettes A. 2012. Species, live status, and diameter are important tree features for diversity and abundance of tree microhabitats in subnatural montane beech-fir forests. Can J For Res 42 (8): 1433-1445

Larrieu L, Gonin P, Deconchat M. 2012. Le domaine d'application de l'indice de biodiversité potentielle (IBP). Rev For Fr 5: 701-710. [France]

Lebourgeois F, Drénou C, Bouvier M, Lemaire J. 2015. Caractérisation de la croissance des chênaies pédonculées atlantiques dépérissantes: effets des sécheresses et relation avec l'architecture des houppiers. Rev For Fr 67: 333-351. [France]

Lebourgeois F, Gomez N, Pinto P, Mérian P. 2013. Mixed stands reduce Abies alba tree-ring sensitivity to summer drought in the Vosges mountains, western Europe. For Ecol Manag 303 (9): 61-71.

Lebourgeois F, Mérian P. 2011. La Sensibilité au climat des arbres forestiers a-t-elle changé au cours du XXe siècle ? Rev For Fr 63 (1): 17-32. [France]
Maitre d'Hôtel E, Pelegrin F. 2012. Les valeurs de la biodiversité : un état des lieux de la recherche française. Rapport FRB, série expertise et synthèse. [France]

Mikusinnski G, Ranius T. 2002. Densities of large living and dead trees in old-growth temperate and boreal forests. For Ecol Manag 161: 189204.

Müller J, Bütler R. 2010. A review of habitat thresholds for dead wood: a baseline for management recommendations in European forests. Eur J For Res 129 (6): 981-992

Nageleisen LM. 2012. Guide de notation de l'aspect du houppier des arbres feuillus dans un contexte de dépérissement. Protocole DEPEFEU. Ministère de l'agriculture, de l'alimentation et de la forêt, DGAL-DSF. [France]

Pastorella F, Paletto A. 2013. Stand structure indices as tools to support forest management: an application in Trentino forests (Italy). J For Sci 59 (4): 159-168.

Rached-Kanouni M, Kara K, Khammar H, Ababsa L. 2020. Floristic diversity and demographic structure of the Sidi R'Ghies forest, northeastern of Algeria. Biodiversitas 21: 875-881.

Rached-Kanouni M, Zerrouki A, Lahmar M, Beldjazia A, Kara K, Ababsa L. 2020. Assessment of the health status of the Sidi R'Ghies forest, Oum El Bouaghi, north-east Algerian. Biodiversitas 21: 1980-1988.

Siitonen J. 2001. Forest management, coarse woody debris, and saproxylic organisms: Fennoscandia boreal forest as an example. Ecol Bull 49: $11-41$.

Vallauri D, Andre J, Genot JC, De Palma JP, Eynard-Machet R. 2010. Biodiversité, naturalité, humanité, Pour inspirer la gestion des forêts. Editions Lavoisier. [France]

Vuidot A, Paillet Y, Archaux F, Gosselin F. 2011. Influence of tree characteristics and forest management on tree microhabitats. Biol Conserv 144 (1): 441-450.

Winter S, Möller GC. 2008. Microhabitats in lowland beech forests as monitoring tools for nature conservation. For Ecol Manag 255: 1251-1261. 